\title{
THE OUTCOME OF CLOSER ECONOMIC LINKS WITH THE EEC FOR LDCS' EXPORTS PREVIOUSLY DUMPED IN WORLD MARKETS
}

\section{AN EMPIRICAL INVESTIGATION}

By ALFRED TOVIAS

\section{Import duties on export goods}

Commeroual policy specialists are sometimes bewildered when analysing the tariffs of many semi-industrialized countries, by the existence of high rates of customs duties on precisely those goods for which these countries are a priori expected to have a comparative advantage in production. Conventional trade theory does not count on the presence of import duties on those foreign goods which directly compete with exportables. ${ }^{8}$ In practice, however, this is a very common case, as will be shown later.

There are a series of answers to the paradox, which are of non-theoretical nature:

1. Internal transport or storage costs may be high enough to prevent arbitrage inside the country, specially if the latter is big and the merchandise conoerned is bulky or deteriorates rapidly. Thus it is perfectly possible that some regions of the country export the same good which other regions import from third countries. This has sometimes been called border trade. A typical case is the oil trade between Canada and the United States, the oil being shipped in opposite directions on the east and west cossts. ${ }^{3}$

2. The tariff position considered may cover quite heterogeneous products, so that the duty really applies only to some of the goods of the category, while others are being exported at international prices and with no imports taking place. Here we recognize the existence of intra-industry trade in differentiated products, due to the existence of economies of scale brought about by long runs operated in particular industries (e.g. chemicals). Partly (but not completely), the problem can be overcome by taking tariffs on highly disaggregated products.

3. The duty may be a historical curiosity or more generally speaking redundant.

However, it is clear that there is a fourth possibility of high relevance

1 I am indebted to Pham Thuy for her help in the computation of statistical material.

2 This does not imply that an export tax exists. But the latter may be charged at the border on the domestic good which leaves the country.

- Other intra-industry trade in functionally homogeneous products must be excluded here, such es trade in easonal producte or entrepot trede, becanse it would be irrationsl in these to impose import duties. For a comprehensive review of the theory of intreindustry trade, see [5]. 
when explaining the trade of aemi-industrialized countries, namely the existence of price discrimination. To illustrate its practical importance, we have included an Appendix with the cases registered by the GATT Committee on Anti-Dumping Practices from mid 1970 till the end of 1975 and reported by GATT members, which either opened an investigation or which took provisional action against the country accused of practising dumping. From the table it clearly appears that there has been an absolute increase in the number of investigations opened against semi-industrialized countries' products. This is also true in relative terms when compared to dumping practices of developed countries. To illustrate the quantitative importance of the trade covered, two figures for each tariff position have been included: world imports originating in the country being investigated and the export market share of the country in total world export trade. The year selected was the one in which the opening of the case took place.

Contrary to the usual assumption of perfect competition in the domestic markets considered, monopoly may prevail. If the local producer is competitive at given world prices and thus can export, the imposition of an import duty allows him to practice discrimination. Domestic consumers will pay a price higher than the world price charged on exports. Of course, the duty stands there in order to prevent the shifting back of exports to the home country at world prices. ${ }^{1}$ Finally one important feature of the economics of dumping should be stressed before proceeding to consider preferential trading: the total quantity produced, ans well as the allocation of resources in the home country, is not affected by the introduction of the tariff, whenever the local monopolist can export the good under Free Trade. ${ }^{2}$ Of course, one must assume that the sector studied is sufficiently small so that the relative price of factors of production is not altered by the introduction of discriminating prices and by the subsequent distortion of relative domestic prices.

This is so because under a profit-maximizing behaviour of the firm the volume produced is uniquely determined by equalizing marginal costs to the given world price. ${ }^{3}$ From the normative point of view, the exploitation of a dumping situation, via the introduction of a prohibitive tariff, only implies (1) a redistribution of income inside the country from consumers to producers, which is considered neutral, assuming that 1 dollar is 1 dollar

\footnotetext{
1 The tariff is prohibitive. Transport costs may also help to prevent the shifting back, spocially in the case of bulky commodities.

- There is no Customs revenue oollected by the Treasury because the duty is prohibitive. Moreover, it is misleading to think of the domestio price in terms of a tariff-inclusive prioe, because there may be 'a lot of water' in the tariff.

- We shall goo later that a real distortion is introducod by the tariff whenever it allows the dumper to export at world prices not oovering its own coste.
} 
for everybody; (2) the appearance of the conventional net loss zone supported by consumers, through the rising of domestic prices over and above the world price. From the international viewpoint there is no distortion whenever the minimum average total cost of the domestic supplier is less than the given world price. In this case, as economists have held for a long time, it is not rational for foreign countries to introduce anti-dumping or other countervailing duties. Only if export prices do not cover average total costs is there ground to accuse the dumper of unfair competition, as most of the national legislations and even article VI of GATT imply. As is well known, the spirit of most of the existing legislation is that there is such a thing as a 'normal' value of the product, which inevitably leads to the conolusion that any other price far below the latter is 'abnormal', thus 'unfair'. The idea is probably that what is sold at these prices does not cover costs. However, one may have serious doubts on the real importance of this case for these reasons: When analysing the Appendix, which gives us a rough idea of the real world situation, it appears that in most cases we can expect the countries concerned have a true comparative advantage in the production of the goods they actually export. They are thus efficient world producers. There is also some indirect evidence supporting our opinion in the report of the Working Party of GATT, adopted recently. ${ }^{1}$ Developing countries stressed that their domestic prices are not a reasonable measure of the 'normal value' of the product and that these should not be used for price comparisons to prove the existence of dumping. According to their view, only export prices applied to third countries should be investigated. Furthermore one developing country said that balance-of-payments difficulties explained the need for high domestic prices. Both statements probably point to the fact that tariffs, which were introduced after the Second World War for infant-industry reasons, have succeeded in stimulating the substitution of imports, a a first stage, and the development of exports later. However, the tariff has not yet ben reduced, allowing dumping in the cases where imperfect competition prevails in the domestio market. Of course, developing countries are caught between two fires when they reply to the accusation of dumping: on the one hand they wish to prove that they are competitive in the products they export. On the other hand, they wish to try to convince developed countries that their domestic prices are not the 'normal' ones, which means of course that they are higher. A neoclassical economist might sympathize with this last idea, in so far as a tariff-inclusive price has nothing to do with the 'normal' price or, for that matter, the 'natural price' concept put forward by the r first Classical economists.

2 Document L/4239, 21 November 1975, reproduced in GATT's Basic Inotruments and Special Dacuments, supplement no. 22. 
2. Customs Union theory and monopolistic price discrimination: explaining Customs Union formation

Joining a Customs Union or a Fre-Trade Ares allows the monopolist who practises dumping in a semi-industrialized country to reach the newly available markets at fixed prices that he cannot influence but which are higher than world market prices. He cannot monopolize his own domestio market any more because the rules of the Free-Trade Area or of the Customs Union imply that the country eliminates its tariffs on trade originating in the region. Thus two effects may be expected to follow simultaneously in the country: a positive consumption effect brought about by the reduction of the domestic price and a negative export-trade diversion effect brought about by the opening of acoess to a high-cost area. There is no import-trade diversion, because the pre-existing tariff in the semiindustrialized country was prohibitive. Note that total exports do not necessarily increase since the additional production may be absorbed by additional local consumption.

The practical implication of these observations is that they help to explain Customs Union or Free-Trade Area formation ${ }^{1}$ in that the conclusion of such kind of agreements may be a way to convince the local producer to drop monopolistic practices and stop asking for protection, while making consumers happier; it is also an intelligent form of selling to the big trading bloc some discriminatory tariff concessions (which will be perceived as reverse preferences) against other direct preferences."

Casual investigation by Victoria Curzon and Robert Middleton on EFTA shows that surprisingly fow dumping cases were investigated during the first decade of existence of this association. In fact, this is not surprising, teking into consideration that the elimination of tariffs in the area allows for price discrimination based only on non-tariff barriers or transport costs. ${ }^{3}$ However, one should not conclude that the aituation has improved from the welfare point of view. In fact what hes happened is that the inefficient monopolist, who would have disappeared as a result of multilateral tariff reduction negotiations, has survived by extending its area of discrimination, although sharing its privilege with the other producers of the Free-Trade Area.

1 There is no difference between adopting one or the other formula, as long as in the latter it is the small somi-industrialized country which adopts the big-oountry tariff.

- The theory of Customs Union formation was elaborated in the last decade by the late H. Johnson and other anthors. It tries to explain better the actual behaviour of governments, and may be seen as a direot oonsequence of the sceptioism brought about by the general theory of the eocond best, developed in the late 1950; ; 160 ].

- Bee V. Curzon [1], pp. 187-40; R. Middleton [8], pp. 86-8. Prioe disarimination could, however, survive in the area if we allow for the existenoe of ahifting effeots ' $\mathrm{B}$ la' Bhibata, $800[11]$. 


\section{A glance at some relevant statistics}

In order to cast some light on to the presumed dumping situation, we have reproduced below Table I which shows GATT duties of six Mediterranean countries for eight selected categories of products. These countries have all concluded partial preferential arrangements with the European

TaBle I

Range of GATT rates of Customs duties

\begin{tabular}{|c|c|c|c|c|c|c|}
\hline $\begin{array}{l}\text { Chapters of the Brussels } \\
\text { Nomenclature }\end{array}$ & Spain & Israel & Mlorocoo & Tunisia & Turkoy & Elgypt \\
\hline $\begin{array}{l}\text { 07.02. Frozen battered } \\
\text { onion rings }\end{array}$ & $\theta \%$ & & & & & \\
\hline 16.04. Tinned sardines & & & $120-50$ & & & \\
\hline $\begin{array}{l}\text { 20. Preparations of } \\
\text { vegetables, fruit, or other } \\
\text { parte of plante }\end{array}$ & & $35-55$ & & 60 & $50-75$ & \\
\hline 29.16. Citric acid & & $\begin{array}{c}10+0.15 \\
\pi / \mathrm{kg}\end{array}$ & & & & \\
\hline $\begin{array}{l}\text { 39. Artiffcial resins and } \\
\text { plastio materials }\end{array}$ & $20-50$ & $20-60$ & & & & \\
\hline $\begin{array}{l}\text { 60/61/65. Knitted and } \\
\text { arooheted goods, articles } \\
\text { of apparel and olothing } \\
\text { acoessories of textile } \\
\text { fabric, headgear and parts } \\
\text { thereof }\end{array}$ & $\begin{array}{l}15-60 \\
\text { (mostly } \\
30-50)\end{array}$ & $\begin{array}{l}\text { Mostly } \\
25-60\end{array}$ & $35-80$ & $20-60$ & $70-100$ & $60-160$ \\
\hline $\begin{array}{l}\text { 64. Footwaar } \\
\text { 87-02. Road vohioles }\end{array}$ & $\begin{array}{l}15-25 \\
50-70\end{array}$ & & & & & $40-70$ \\
\hline
\end{tabular}

Bouroe: National Tariff Schedules; International Customs Journal, International Oustoms Tariff Bureau, Bruseals, 1875-6.

Economic Community in the late 1960s and early 1970s..$^{1}$ Moreover, as a second stage of the process and in the framework of what has been called the Mediterranean Policy of the EEC, some of them have already signed Free-Trade Area agreements with the Community (Israel, 1975; Morocco, 1976; Tunisia, 1976). We have indicated the extreme values of the range of ad valorem taxes applied to the goods covered by each of the categories of the Brussels Tariff Nomenclature. No figure was included when some duties of the corresponding category were zero, as justified on p. 127, n. 1, nor when there were specific duties or non-tariff barriers instead of ad valorem taxes. There was also no point in including the range of duties when the corresponding export figures included in Table $\amalg$ were not available. This table was set up by selecting first the Standard International Trade Classification (SITC) categories, at the 3- or 4-digit-level

1 Turkey conoluded an assosiation agreement with the EEC in 1963, whioh should lead to the areation of a common Customs Union after an interim period of twenty-two years. Thus do facto only partial preferential trading prevails up to the present. 
TABLE II

Column 1: Total oxports in value (millons s) 1070

Column 2: Export market share in OECD import trade, 1970 (tn \%)

Column 3: Total imports in value (millions s) 1970

\begin{tabular}{|c|c|c|c|c|c|c|c|c|c|c|c|c|c|c|c|c|c|c|}
\hline & \multicolumn{3}{|c|}{ Spain } & \multicolumn{3}{|c|}{ Israed } & \multicolumn{3}{|c|}{ Moraces } & \multicolumn{3}{|c|}{ Tuniria } & \multicolumn{3}{|c|}{ Turkoy } & \multicolumn{3}{|c|}{ EFonpt } \\
\hline & 1 & $\mathbf{2}$ & 8 & 1 & 2 & 3 & $\mathbf{1}$ & 2 & 8 & 1 & 2 & 8 & 1 & $\mathbf{2}$ & 8 & 1 & 8 & 8 \\
\hline $\begin{array}{l}\text { Fromen betterod onton } \\
\text { ringes }\end{array}$ & 188.893 & 18 & 10.505 & & & & & & & & & & & & & & & \\
\hline Tinned sardines & & & & & & & 58.050 & 8 & - & & & & & & & & & \\
\hline $\begin{array}{l}\text { Proparation of vegetable } \\
\text { frult, or other parts of } \\
\text { plants }\end{array}$ & & & & 40.118 & 3.14 & - & & & & 3.444 & 0.27 & 一 & 6.504 & 0.48 & - & & & \\
\hline Citrte acid & & & & 4.668 & 0.87 & - & & & & & & & & & & & & \\
\hline $\begin{array}{l}\text { Artuficlal resins, plastlc } \\
\text { matarinls }\end{array}$ & 10.790 & 0.37 & 78.784 & 8.046 & 0.10 & 17.764 & & & & & & & & & & & & \\
\hline $\begin{array}{l}\text { Knitted and crochoted } \\
\text { goods, artitcles of apparel } \\
\text { and chothlng aocesories } \\
\text { of textllo fabrte, head- } \\
\text { gear and parts thereof }\end{array}$ & 47.051 & 0.09 & 13.258 & 51.275 & 1.08 & $2.2 \$ 1$ & 4.085 & 0.10 & - & 1.000 & 0.02 & 1.139 & 4.175 & 0.08 & - & 10.168 & 0.21 & - \\
\hline Footwrear & $\begin{array}{r}104.861 \\
84.700\end{array}$ & $\begin{array}{l}7.12 \\
0.33\end{array}$ & $\overline{96.751}$ & & & & & & & & & & & & & 2.805 & - & 28.770 \\
\hline
\end{tabular}

Sources: Yarbook of Inlemational Trade Statietice $1970-1975$, Unlted Nations, Now York, 1873.

Statiotioal Papere, serias M, no. 34, Standard Intornational Trade Clasvification, Retied, United Nattons, New York, 1961. 
of aggregation, which correspond exactly to the Brussels Nomenclature tariff positions chosen. For each Mediterranean country three figures have been considered: total exports by value, export shares of the concerned country in total OECD import trade and total imports of these countries from the OECD area. The last figure has been included in order to give some notion of the heterogeneity of the particular SITC class.

The first two figures give a rough idea of the importance of this export trade. From the statistics analysed it appears that, notwithstanding the fact that some of the daties may be redundant, ${ }^{1}$ there must be some price discrimination, given the importance of most of the duties. Of course, the lower the Mediterranean country import figure is, the higher the probability of existence of dumping. Thus plastio materials both in Spain and in Israel must be regarded with caution.

Road vehicles in Spain may be an industry where dumping may appear because oligopolistic market structures prevail in this sector. On the other hand, clothing in the six countries considered should be dropped from this study as apparently atomistic market conditions prevail in all these cases. An interesting case is footwear in Spain because it seems to be a priori an awkward example of potential dumping due to the well-known existence of thousands of small production units. However, as spelled out in the appendix to the article, Spain has been accused of practising dumping in the past in this field (women's footwear, 1870).

Middle-of-the-road cases are canned products (vegetsbles and fruits) in Israel, Tunisia and Turkey, where the existence of large government intervention (such as export government bodies or nation-wide co-operative organizations) allows for the existence of cartel conditions. When we look at factual cases (see Appendix), we see that in these last years, dumping investigations were opened on green olives packed in glass coming from - Spain, and on apple juice concentrates originating in Greece. For instance, the import duty rate applied by this last country on the same product is 42 per cent. And the same happens for other products in which both countries play a leading role in world trade (i.e. steel reinforcing bars and ceramic floor tiles, both mentioned in the Appendix).

However, the clearest examples of dumping by Mediterranean countries, where the high domestic tariff played a crucial role, are the cases of tinned sardines of Morocco and of onion products from Spain. Here we have two products where both countries play an important role in world trade and where the product selected was homogeneous, while imports into the two countries were small, due to the presence of customs duties on both commodities in the two Mediterranean countries considered.

1 Note that because the export figure may correspond to duty-free goods, ranges of tariffs starting at zoro havo boen excluded from Table I. 
From this rapid survey of the actual situation, we can state that price discrimination, due to the combined existence of monopoly conditions and protective import duties, is a relevant issue when examining trade relations of semi-industrialized countries with developed countries. The issue will probably come to the forefront of future negotiations between Spain, Portugal, and Greece on the one hand, and the European Economic Community on the other, for the entry of the former into the EEC. The model presented may be of some use to explain the interests of the different partners involved in these negotiations.

To illustrate the relevance of the observations presented above, plastic materials in Israel (chapter 39) in Table I have been selected as a case study. This conntry is supposed to eliminate its import duties on this tariff position by 1985 under the Free-Trade agreement signed in May 1975 with the EEC. The prevailing rates of the Common External Tariff of the EEC lie between 7 and 18.4 per cent. ${ }^{1}$ Positive consumption effects to be reaped by Israeli local users are to be small due to the fact that plastic materials are mostly intermediate products, with low demand price elasticities. On the other hand, important redistribution effects may take place, considering the fact that local gross production amounted to more than 47 million dollars in 1970.2 But for the country as a whole the net outcome of free access to the plastic materials market to the EEC may be low or even negative in view of the inefficient and artificial development of this branch of industry.

\section{Some final remarks}

The object of this paper was to show that a dumping situation exploited by the producers of a small country in a free-trade environment promotes mainly a redistribution of income in this country bat not a distortion in the allocation of resources. When the country decides to join a trading club by signing a free-trade arrangement with it, covering the sector in which dumping takes place, the first effect tends to disappear, while a real distortion emerges from the new situation, brought about by export trade diversion from third countries towards the partner country implying a waste of resources since production is artificially extended.

As shown, there is some empirical evidence that semi-industrialized

1 Thee tariffs already take into socount Kennedy Round developmente although the final reduotions epplied were less than the saheduled ones, due to their conditional acceptance againgt the elimination of the well-known American Belling Prioe regulation by the U.S.

1 This flgure inoludes also synthetio rubber as well as man-made fibres, which are mainly covered by ahaptere 40, 61, and 66 of the Bruseals Nomenclature. See The Growth of World Industry, 1971 edition, vol. i, General Industrial Statistios, 1961-70, United Nations, New York, 1973. When man-made fibrea are edded to the general export figure for plastio materials included in Table $\mathrm{L}$, the Israel total amounts to more than $\$ 20$ millions. 
countries around the Mediterranean are practising (maybe involuntarily) dumping in neighbouring developed countries, by letting up-dated highlevel tariffs subsist in sectors where they have acquired, in the process of industrialization, comparative advantage. Their progressive economio association with the EEC is eliminating this highly visible and irritating distortion by supressing redundant tariffs, but at the same time these countries are undoing a part of the progress made since the beginning of industrialization by fostering production at a cost no longer competitive at the world level.

\section{University of Geneva}

\section{REFERENCES}

1. Cunzon, V., The Esesentials of Economio Integration, London, Macmillan, 1974.

2. GATT (1969), Agreoment on Implementation of Article VI (Anti-Dumping Code).

3. GATT. BISD, supplement no. 22, Feb. 1876.

4. GATT (1970). Legislation Antidumping (Lois et réglements antidumping des Parties a l'Accord relatif a le mise en ouvre de l'Article VI de l'Accord général sur les tarifo douaniers et le commerce).

5. Grober, H., and LloYd, P., Intra-Industry Trade, London, Macmillan, 1975.

6. JoHrson, H., 'An exonomic theory of protection, tariff bargaining, and the formation of customs unions', J. Political Economy, 63, 260-82.

7. KRAU8s, M., 'Recent developments in customs union theory : an interpretive eurvey', J. Economio Literature, 10 (1872), 413-36.

8. Muduetow, R., Negatiating on Non-Tariff Distortione of Trade: The EFTA Precedonto, London: Macmillan, 1975.

9. Pourfart, R., The Consequonces of Free Trade in Manufactures between Ioracl and the EEO, Kiel : Kiol Working Papers, No. 51, 1976.

10. SoHLAns, A., and YaNNOPOULOs, G. N. (eds.), The EEC and the Mediterranean Countries, Cambridge University Press, 1976.

11. Shibata, H., 'A theory of free trade areas', Robson, P., International Economic Integration, Harmondsworth, Penguin Books, 1971, pp. 68-87. 
Investigations opened on alleged dumping practised by semi-industrialized countries; exports concemed and country's axport market share in woorld trade

Year

1970

1970

1970

1970

1970

1970

1971

1971

1971

1971

1871

1871

1971

1971

1971

1971

1971

1971

1872

1972

1972

1873

1873

1973
Product

Files and respes

Fertilizers

Women's footweas

Gless gheet

Pig-iron

Gelatine explosives

Stoel pipes

Ammonium nitrate fertilizers

Eggs, ahicken in the shell

Sulphur

Monochrome and colour television

Bicycle tyres and tubes

Apple-juice concentrate

Carpets of coconut fibre and thread

Wire

Yarns of acrylio fibres

Yarns of acrylio flbrea

Wood ohipboard

Steel-wire rope

Vinyl film printed

Iron for reinforced concrete and steel sheets

Complex ternary fertilizers

Vecuum vessels

Maleic anhydrine

\section{Products' \\ origin}

Portugal

Greece

Spain

Taiwan

Brazil

Yugoslavia

Spain

Yugoslevia

Mexico

Mexico

Taiwen

Taiwen

Greece

India

India

Taiwan

South Korea

Portugal

Teiwen

Brazil

Spain

Yugoslavia

Hong Kong

Spain

\section{Exports of the}

given year

(valuse in

millions \$)

1.493

4.491

104.361

N.A.

23.786

2.841

6.948

1.877

N.A.

16.820

N.A.

N.A.

24.731

25.843

0.276

N.A.

9.023

4.012

N.A.

1.612

6.223

N.A.

13.470

N.A.
Export market

share in woorld

imports (in \%)

0.08

0.34

6.36

N.A.

2.09

1.70

0.74

0.39

N.A.

6.73

N.A.

N.A.

2.38

2.48

0.05

N.A.

N.A.

0.79

N.A.

0.14

0.56

N.A.

0.34

N.A. 
Year

1973

1873

1973

1973

1873

1873

1973

1873

1873

1873

1873

1873

X

1873

1073

1873

1073

1974

1874

1074

1074

1874

1974

1974

1074

1974

1875

1875

1875
Product

Steel files

Steel files

Liquid eprayers

Deformed steel reinforoing bars

Picker atioks (for textile machines)

Vinyl film printed

Tile, ceramio glazed wall

Egg products

Egg products

Green olives, packed in glacs

Ternary compound fertilizers

Acrylic-fibre socks

Acrylio-fibre socks

Saccharin and its salts

Self-adhesive photo albums

Transit car seats

Polypropylene and polyethylene rope

Colour TV sete

Frozen battered onion rings

Ramin dowels and mouldings

Ramin dowels and mouldings

Plywood paper overlaid or printed

Plywood paper overlaid or printed

Louvred doors

Tinned sardines

Playing cards

Fibreglass flshing-rods

Fibreglase fishing-rods

\section{Products \\ origin}

India

Portugal

South Korea

Mexico

Mexico

Argentina

Philippines

Israel

Yugoslavia

Spain

Yugoslavia

South Kores

Taiwen

South Kores

South Kores

Brazil

South Korea

Singapore

Spain

Singapore

Malaysia

Singapore

Taiwan

Tairtan

Moroceo

Hong Kong

Taiwan

South Korea
Exports of the given year (value in millions \$)

0.022

1.086

N.A.

N.A.

0.215

2.631

3.060

2.087

0.407

91.361

N.A.

2B.439

N.A.

N.A.

20.028

20.680

N.A.

37.400

183.393

4.427

14.742

58.878

N.A.

N.A.

58.080

10.479

N.A.

N.A.
Export market share in world imports (in \%)

0.005

0.23

N.A.

N.A.

0.03

0.18

0.51

0.47

0.09

5.45

N.A.

1.45

N.A.

N.A.

0.84

0.18

N.A.

$1.5 \theta$

10.72

0.37

1.25

4.673

N.A.

N.A.

7.21

0.48

N.A.

N.A. 


\begin{tabular}{ll} 
Year & \multicolumn{1}{c}{ Product } \\
1975 & Oil and air filters \\
1975 & Hardboard \\
1975 & Acrylio aheet \\
1975 & Citric acid \\
1975 & Citrio acid \\
1975 & Slide projectors \\
1975 & Files and rasps \\
1975 & Natural rubber (latex) balloons \\
1975 & Battery post and terminal oleaning brushes \\
1975 & Wooden clothes-pins \\
1975 & Wood panels \\
1975 & Steel reinforoing bars \\
1975 & Ladies raincoats \\
1975 & Portland hydraulic cement \\
1975 & Multi-metal lithographic plates \\
1975 & Monosodium glutamate \\
1075 & Ceramic floor tiles
\end{tabular}

\begin{tabular}{|c|c|c|}
\hline $\begin{array}{c}\text { Products' } \\
\text { origin }\end{array}$ & $\begin{array}{l}\text { Exports of the } \\
\text { given year } \\
\text { (value in } \\
\text { millions 8) }\end{array}$ & $\begin{array}{l}\text { Export market } \\
\text { share in world } \\
\text { imports (in \% }\end{array}$ \\
\hline Israel & N.A. & N.A. \\
\hline Philippines & 48.629 & 1.75 \\
\hline Taiwan & N.A. & N.A. \\
\hline Isreel & 4.652 & 0.21 \\
\hline Mexico - & N.A. & N.A. \\
\hline Singapore & 2.358 & 0.11 \\
\hline India & 6.296 & 0.19 \\
\hline Mexico & N.A. & N.A. \\
\hline Hong Kong & 59.466 & 1.66 \\
\hline Hong Kong & 5.790 & 0.49 \\
\hline Brazil & 18.349 & 1.66 \\
\hline Spain & 66.245 & 8.05 \\
\hline Hong Kong & 104.728 & 6.34 \\
\hline Mexico & N.A. & N.A. \\
\hline Mexico & N.A. & N.A. \\
\hline South Korea & N.A. & N.A. \\
\hline Spain & 64.351 & 3.82 \\
\hline
\end{tabular}

Souroes : GATT, Committes on Anti-Dumping Practices; United Nations, Yearbook of International Trade Statistics, 1972-3, 1975 (vol. II). N.A. = not available. 